the end of the book. Although not neglected, less prominence is given to them and to the current tenets of membrane physiology on which they are based than in some recent texts such as Goldstein's Introduction to Comparative Physiology (Holt, Rinehart \& Winston, 1977) and Eckert and Randall's Animal Physiology (W.H. Freeman, 1978) where they follow the opening chapters on physical and chemical principles.

In style the book is densely and didactically written but the terse generalization is usually supported by example or the brief report of an observation or experiment. Nevertheless, I found myself wondering whether an introductory text ought not to lead readers more gently along the path of interest rather than seek to impress them with sheer quantity of information. Unlike some bulky and extravagant textbooks, this one is handy and well produced apart from a few gimmicks such as two contents lists, one short and obscure and one detailed and eleven pages in length! There is no indication of part or section in the running headlines, which makes cross-reference difficult since such references are frequently indicated by subdivision and not by page. Bibliographical references (not indicated in the text) are divided into annotated, at the end of each part, and "credit" - whatever they may be - at the end of the volume.

In short, this seems a somewhat daunting introductory text to read although good indexing increases its value to an industrious student for purposes of reference and study.

Garth Chapman is Professor of Zoology at Oueen Elizabeth College, University of London.

\title{
Enzymology: the general and the specific
}

\section{R.N. Perham}

Understanding Enzymes. By Trevor Palmer. Pp.405. Hbk ISBN 0-85312-202-4; pbk ISBN 0-85312-307-1. (Ellis Horwood, Chichester/Halsted: 1981.) Hbk £25, $\$ 80.95$; pbk 99.50. Molecular Enzymology. By Christopher W. Wharton and Robert Eisenthal. Pp.326. ISBN 0-216-91012-9. (Blackie/Wiley: 1981.) £19.75, \$46.95. Isoenzymes. By C.C. Rider and C.B. Taylor. Pp.78. Pbk ISBN 0-421-15640-7. (Chapman \& Hall/Methuen: 1981.) £2.45, \$5.95. Enzyme Kinetics: The Steady-state Approach, 2nd Edn. By P.C. Engel. Pp.96. Pbk ISBN 0-412-23970-1. (Chapman \& Hall/Methuen: 1981.) £2.45, \$5.95.

THERE is hardly a corner of biochemistry or molecular biology - not to mention the cognate biological and chemical sciences where modern ideas of enzymology have not intruded to good effect. The study of enzymes is therefore properly an important part of all degree courses in these subjects, and there continues to be no shortage of authors willing to try their hand at providing the necessary textbooks.

Dr Palmer's offering, Understanding Enzymes, attempts to cover all of the fascinating aspects of enzymes, from their biosynthesis to their structure, chemical mechanisms and kinetics, from their place in metabolism to their use in medicine and industry. It is an heroic task but one of dubious practicability - witness how few authors have followed the trail so comprehensively blazed by Dixon and Webb in their classic first edition of Enzymes, published by Longman. Thus one should not be surprised that in the volume under review, which is furthermore written by a single author, the coverage is uneven and appears to rely heavily on secondary sources. It is sad to record that some of those sources are significantly out of date. For example, in the short chapter on protein structure nothing published since 1970 is suggested for further reading, the chapter on biosynthesis of proteins (surely now misplaced in a book on enzymes) has no specialist reference later than 1974, and the chapter on metabolic regulation includes a diagram of the cell that places the cisternae of the rough endoplasmic reticulum in unrestricted communication with the extracellular environment. The kinetics of enzymes are dealt with more extensively and sympathetically, and the later sections on technological and medical applications of enzymology cover a wide range of topics. Each of the 20 chapters concludes with a useful summary of its contents and most carry a set of problems and answers. In what I take to be an otherwise commendable attempt to lower costs, many of the illustrations, though clear, appear to have been left as sketches, which adds a slightly makeshift air to the printed page.

All in all, I cannot see this book supplanting the more narrowly based texts on which the undergraduate teaching of enzymology normally rests, though the convenience of a broad range of topics falling within a single volume may commend it to those with less stringent needs.

A new contender for a place among the more specialized texts is Molecular Enzymology by Wharton and Eisenthal, which assumes a basic knowledge of university biochemistry and chemistry. The approach is first to tackle the chemical aspects of catalysis and the properties of enzymes as proteins, to develop ideas in enzyme kinetics and then to deal in some depth with the mechanisms of eight or nine selected enzymes as examples. The book concludes with a return to the practical problems of studying enzyme kinetics in the laboratory. The treatment is clear and conventional, cuts few corners and makes plain the complementarity of the different methods; it should appeal particularly to those with a background in the physical sciences. The bibliography is sound and extensive. The authors eschew the usual efforts to represent threedimensional events on paper in favour of a more descriptive turn-by-turn account of the involvement of amino acid side-chains and other functional groups, an approach with which I do not altogether agree. And at the risk of a charge of chauvinism, I suggest that any new text on molecular enzymology that largely neglects protein mobility and dynamics, multienzyme systems and multifunctional proteins cannot be regarded as complete. These quibbles apart, I found little to quarrel with and expect the book to find an honourable place in university reading lists.

Finally, it is a pleasure to notice two further additions to the series of Outline Studies in Biology. The first, Enzyme Kinetics by Engel, is the second edition of his successful account of steady-state kinetics and their contributions to problem-solving in enzymology. The second, Isoenzymes by Rider and Taylor, describes the importance of isoenzymes in a broad range of biochemical and medical contexts. Both are clear, unpretentious and informative, in accord with the general style of this well-known series.

R.N. Perham is Reader in Biochemistry of Macromolecular Structures at the University of Cambridge, and a Fellow of St John's College, Cambridge.

\section{Spanning a bridge}

\author{
Peter H.W. Butterworth
}

Biochemistry, 2nd Edn. By Lubert Stryer. Pp.949. Hbk ISBN 0-7167-1226-1; pbk ISBN 0-7167-1306-3. (W.H. Freeman: 1981.) Hbk \$32.95, £24.40; pbk £12.95.

THERE are a lot of biochemistry textbooks and, as the borders of the subject continue to be extended, there will be more. Some adopt a particular emphasis; others attempt a comprehensive approach to the subject. Lubert Stryer's text belongs to the latter genre and it is doubtful whether there will be another which will appeal to the student as strongly as this one does. When the first edition appeared, immediate reaction was dominated by the impact of the remarkable illustrations and the succinct text. Familiarity with the book brings with it the realization of how 